\title{
- ІСТОРІОГРАФІЯ ВІТЧИЗНЯНИХ НАУКОВИХ ДОСЛІДЖЕНЬ МУЗИЧНОЇ КУЛЬТУРИ В СУЧАСНИХ УМОВАХ
}

\author{
- Могилевська Наталія Олексіївна \\ Народна артистка України, \\ ORCID: 0000-0002-7102-2114, e-mail: mogylevska-nataliia@ukr.net, \\ Київський національний університет культури і мистецтв, \\ вул. Є. Коновальця, 36, Київ, Україна, 01133
}

\section{- Для цитування:}

Могилевська, Н.О.(2021). Історіографрія вітчизняних наукових досліджень музичної культури в сучасних умовах. Питання культурології, (38), 133-142. doi: https://doi.org/10.31866/24101311.38.2021.245799.

\section{- Анотація}

У статті розглядаються умови здійснення дослідження музичної культури, які впливають на розвиток наукових знань. Мета статті - з'ясувати особливості розвитку наукових досліджень музичної культури в умовах сучасної України в контексті національних та глобальних процесів. Методологія дослідження полягає у загальнонаукових і спеціальних методах. До перших належать логічний і діалектичний методи, а до других - системний та історико-порівняльний. Висновки. Визначено, що на початковому етапі досліджень музичної культури багатьом доробкам був властивий перехідний формат, однак відкриття нових архівних матеріалів та доступ до світових досягнень змінили ситуацію в напрямку розвитку міждисциплінарного підходу, який змушує переглянути встановлені стереотипи. Наголошується, що в процесі рефрормування як держави в цілому, так і окремих її інститутів значний вплив на розвиток досліджень музичної культури відіграла боротьба із плагіатом та вимога розширення публікацій у наукометричних базах. Однак вищі навчальні заклади і академічні наукові установи не змогли позбутися бюрократичного контролю, а в процесі реформування не було запропоновано формули, за якою наукова спільнота могла б визначати ефрективність оприлюднення наукових результатів. Підкреслюється національний та глобалізаційний вплив на ефективність діяльності науковців. Визначено, що на сьогодні вже можна говорити про існування ряду наукових центрів, де вивчаються проблеми музичної культури, зокрема - це Національна музична академія України ім. П. І. Чайковського, Київський національний університет культури і мистецтв та інші установи. Тож нагромадження позитивних змін проявилося в наукових ідеях, дослідженні нових тем і впровадженні наукових результатів у навчальний процес чи практичну діяльність державних установ та громадських організацій. 
Ключові слова: музична культура; наука; журнал; пострадянський період; глобалізація; національні інтереси; Київський національний університет культури і мистецтв; академічна доброчесність

\section{- Вступ}

Музична культура як невід'ємний елемент розвитку суспільства постійно перебувала у сорері наукових інтересів, передовсім культурологічного характеру. Однак рівень досліджень, їх спрямованість та актуалізація залежала від суспільних процесів і його потреб. На сьогодні цей процес зумовлюється національним і глобалізаційним факторами, євроінтеграційним рухом українського суспільства та необхідністю реформування власної держави.

Вивченню музичної культури присвячена значна кількість наукових доробок. Водночас історіографічних досліджень, які б враховували сучасні суспільні умови та їх особливості, створено ще не було. Звісно, у окремих статтях, монографіях та дисертаціях $€$ певні напрацювання. Зокрема, відзначимо публікації Володимира Іонова (2014), однак його розуміння поняття «історіографрія» має особливий характер, під яким розуміється інше поняття - «історіософія». Частково теми історіографії музичної культури торкнувся доктор мистецтвознавства Володимир Рожок (2017) у статті «Національна музична академія імені П. І. Чайковського - науковий центр Європи». Однак, із нашого погляду, узагальнюючих вітчизняних історіографрічних досліджень немає. Водночас цій темі взагалі не приділялася увага і в іноземних наукових працях.

\section{- Мета статті}

Мета дослідження - з'ясувати особливості розвитку наукових досліджень музичної культури в умовах сучасної України і в контексті національних та глобальних процесів та визначити ті фактори, що впливають на них. Методологія дослідження полягає у загальнонаукових і спеціальних методах. До перших належать логічний і діалектичний методи, а до других - системний та історико-порівняльний.

\section{- Виклад матеріалу дослідження}

Розпочавши у XIX столітті дослідження музичної культури, українське наукове середовище змушено було, певним чином, протистояти різноманітним соціальним, ідеологічним та іншим впливам офіційної ідеології Російської імперії, а в радянський період, відповідно, комуністичної. У пострадянський період методологія наукових досліджень стає більш об'єктивною та різноманітною, хоча багато в чому ще спиралася на певні радянські постулати («дружба народів» тощо). Поступово наукові розвідки українських вчених стають більш європоцентричними і одночасно національно спрямованішими.

В часи незалежності сорормувалося кілька наукових центрів, де безпосередньо здійснюються дослідження музичної культури України і світу. Насамперед - це вищі навчальні заклади спеціалізованого напряму (Київський національний університет культури і мистецтв, Національна музична академія України ім. П. І. Чайковського, Національна академія керівних кадрів культури 
і мистецтв та ін.). Окрім того, музична культура вивчається і в багатьох інших навчальних та академічних закладах, а також окремими зацікавленими особами, які безпосередньо не дотичні до такого типу закладів.

Результати наукових досліджень на означену тематику представляються на конференціях, публікуються у спеціалізованих фрахових виданнях, монографіях, захищаються кандидатські та докторські дисертації.

Серед фрахових видань, в яких висвітлюються наукові результати з теорії та практики музичної культури, передусім виділимо: «Питання культурології», «Культура і мистецтво у сучасному світі», «Вісник Київського національного університету культури і мистецтв. Серія: Музичне мистецтво», «Культура і сучасність», «Вісник Національної академії керівних кадрів і культури», «Мистецтвознавчі записки», «Науковий вісник Національної музичної академії України ім. П. І. Чайковського», «Українське музикознавство» та інші. Така кількість видань свідчить, що музична культура $є$ однією з найбільш досліджуваних тем в сучасному українському просторі. Наприклад, у рамках часопису «Вісник Київського національного університету культури і мистецтв. Серія: Музичне мистецтво» за останні чотири роки (2018-2021) було оприлюднено 7 випусків, у яких, зі свого боку, побачили світ 66 різнопланових наукових публікацій. $€$, звичайно, і видання, що почали виходити значно раніше та за багато десятиліть здобули в науковому середовищі власний академічний авторитет. До таких належить журнал «Українське музикознавство», що почав видаватися ще у 1965 році, який оприлюднив 46 випусків (щорічно по 1-му тому). За останні чотири роки у цьому виданні надруковано 50 статей. Аналогічну картину ми можемо бачити і стосовно багатьох інших наукових видань.

На сучасні наукові дослідження музичної культури безпосередньо впливають існуючі проблеми методологічного характеру. Звісно, вони мають індивідуалізований характер, оскільки кожен дослідник сам визначається з тим, якими методами та способами досягати відповідних результатів. Однак спостерігається певна вузькість у багатьох працях. Пов'язана вона з певною традиційністю і спрощеністю авторських підходів.

Наголосимо, що на початковому етапі досліджень музичної культури пострадянського періоду для багатьох публікацій був властивий перехідний формат, що виявлявся у певному наслідуванні попередньої методології та використанні застарілої інформації, доступної чи то у старих імперських виданнях, чи то в радянських. Це зумовлювалося тим, що на початку 1990-х років ще не було достатньої кількості напрацювань і обмежувався доступ до іноземних джерел. Звісно, така ситуація дещо гальмувала науковий поступ. Однак від рубіжного часу 1990- 2000-х ситуація поступово змінюється. Цьому сприяють як технології, так і інтеграційні процеси в Україні.

Останніми десятиліттями значний вплив на вивчення музичної культури спричинив її зв'язок з іншими науковим напрямами - історією, фрілософрією, релігієзнавством тощо на основі міждисциплінарних досліджень. Однак відкриття нових архівних матеріалів та доступ до світових досягнень із цього напряму ситуацію змінили. Наразі поєднання різних наукових напрямів (т. зв. міждисциплінарний підхід) призводить до досить несподіваних результатів, які змушують 
переглянути встановлені стереотипи. Наприклад, надзвичайно цікаві думки висловлені Іваном Кузьмінським $(2014,2018)$, який у своїх публікаціях стверджує про новації в історії української музики, що фоомувалися на взаємовпливі західної та східної релігійних культур. Згодом саме у такому контексті відбулося дисертаційне дослідження Миколи Підгорбунського (2021) «Запровадження багатоголосої музики в українській духовній культурі в контексті реформаційних впливів».

Відзначимо також певний вплив наукової реформи, адже деякі спроби у цьому напрямі вказують на суспільний запит ії̈ впровадження. Це передусім пов'язано із широкомасштабною «антиплагіатною» кампанією, створенням НАЗЯВО (Національне агентство із забезпечення якості вищої освіти), переформатуванням умов формування редакційних колегій наукових видань, вимогою розміщення публікацій у виданнях, що індексуються в базах Scopus та Web of Science, тощо (Київський національний університет культури і мистецтв, 2019). Незважаючи на достатньо позитивний ефект реформування, зазначимо іï частковий характер. Проблема виникає з того, що вищі навчальні заклади і академічні наукові установи не позбулися суто бюрократичного контролю за науковою діяльністю, не було запропоновано такої формули, якою б сама наукова спільнота могла визначати ефективність оприлюднення наукових результатів. Ця проблема є достатньо давньою в українському середовищі, але поки що нерозв'язаною (Скрипнюк, 1999).

Виділимо також національний та глобалізаційний фактори, що впливають на тенденції сучасних вітчизняних досліджень музичної культури. Національний - визначається історичними, політичними та економічними потребами суспільства, особливо після подій 2013-2014 років, пов'язаних із Революцією гідності та війною на сході України, коли інтерес до музичної культури (як і інших сфрер суспільного життя) отримав новий сплеск (Потапенко, 2015). Це пов'язано з певним бажанням самоідентифікації, у т. ч. й за допомогою музики.

Вплив глобалізаційних процесів на дослідження музичної культури позначається у кількох ракурсах: по-перше, у доступності інформації та джерел з усього світу; по-друге, у розширенні меж спілкування та комунікації для вітчизняних дослідників завдяки відкритості кордонів; по-третє, бажання самоідентифікації спонукало науковців вивчати не лише власну музичну культуру, але й інших держав та народів, у т. ч. і в контексті взаємопроникнення та взаємовпливів. Наприклад, на сторінках «Українського музикознавства» були опубліковані праці, присвячені італійській опері в Одесі, європейському баченню Петером Етвешем японської традиції у його оперних творах, творам турецьких композиторів та ін. А у часописі «Вісник Київського національного університету культури і мистецтв. Серія: Музичне мистецтво» у 2021 році фрактично цілий номер (том 4, № 1) був присвячений музичній культурі Азербайджану і вміщував наукові публікації із цієї теми.

Звісно, найбільше описані тенденції проявляються під час оприлюднення та захисту дисертаційних досліджень. Так, завдяки діяльності спеціалізованих Вчених рад при Київському національному університеті культури і мистецтв за період 2012-2021 років було захищено не менше 16 дисертацій (кандидатських та докторських), які безпосередньо були присвячені музичній культурі (при цьо- 
му ми не враховуємо дисертаційні дослідження, в яких ця тема вивчалася опосередковано). Про інтенсивність цього процесу і нарощування наукових можливостей свідчить те, що тільки в 2021 році, окрім вже згадуваної роботи Миколи Підгорбунського, з'явилися розвідки, присвячені сучасній електронній музиці в Україні (Андрій Бондаренко, 2021), народно-інструментальному мистецтву Півдня України (Віта Шеремет, 2021), стилю bebop у джазовій музичній культурі США (Володимир Журба, 2021) та впливу блюзу на неакадемічну музику (Яніна Журба, 2021).

Важливо відзначити позицію доктора мистецтвознавства Володимира Рожка, який обґрунтовано вважає Національну музичну академію України ім. П. І. Чайковського справжнім науковим європейським центром. Із цим, звісно, не можна не погодитися, адже наукові здобутки дослідників Академії визнані на міжнародному рівні. В. Рожок (2017) наголошує, що, незважаючи на складний для держави час, коли фінансування культури вкрай обмежене, науковопедагогічному колективу Академії все ж вдається організовувати заходи і залучати до участі в них науковців не лише з різних міст України, а й інших країн: Австрії, Білорусі, Голландії, Греції, Ізраїлю, Італії, Росії, США, Хорватії, Чехії та ін. Наприклад, у часописі «Українське музикознавство» бачимо і прояв зацікавленості європейських дослідників у публікаціях на українському науковому просторі. Йдеться про розвідку Кевіна Мелоуна (Malone, 2017) із Великої Британії на тему фемінізму в музичних творах.

У 2017 році на базі Академії було організовано та успішно проведено понад 20 наукових конференцій різних рангів: міжнародні, всеукраїнські, загальноакадемічні та кафедральні, а також симпозіуми і семінари (Рожок, 2017). Відзначимо також, що подібні наукові центри є й в інших установах України, зокрема, у Київському національному університеті культури і мистецтв.

Нагромадження позитивних змін, що відбувалися в країні в цілому, дали результати у вивченні музичної культури. Це проявлялося і в наукових ідеях, і у дослідженні нових тем, i, зрештою, у впровадженні наукових результатів у навчальний процес чи практичну діяльність державних установ та громадських організацій. Зокрема, з'являються дисципліни, що безпосередньо присвячені відкриттям у сорері музичної культури. Наприклад, у Національній музичній академії України імені П. І. Чайковського була введена в навчальний процес дисципліна з дуже промовистою назвою - «Українська музична спадщина: нові відкриття» (Шевчук, 2021). Новаторською у цьому сенсі $є$ і дисципліна «Музичне краєзнавство», що була запроваджена у Львівському національному університеті імені Івана Франка (Медведик, 2018).

\section{- Висновки}

Таким чином, на початковому етапі досліджень музичної культури багатьом доробкам був властивий перехідний формат, що виявлявся у наслідуванні попередньої методології та використанні застарілої інформації. Однак відкриття нових архівних матеріалів та доступ до світових досягнень змінили ситуацію в напрямку розвитку міждисциплінарного підходу, який змушує переглянути встановлені стереотипи. 
Відзначимо також певний вплив наукової рефрорми, що проявилася в «антиплагіатній» кампанії, створенні НАЗЯВО, перефрорматуванні редакційних колегій наукових видань, вимозі розміщення публікацій у виданнях Scopus та Web of Science. Водночас вищі навчальні заклади і академічні наукові установи не позбулися бюрократичного контролю за науковою діяльністю, не було запропоновано формули, за якою наукова спільнота могла б визначати ефективність оприлюднення наукових результатів.

Виділимо національний та глобалізаційний фрактори впливу на тенденції сучасних вітчизняних досліджень музичної культури. Національний - визначається історичними, політичними та економічними потребами суспільства, а глобалізаційний - доступністю інформації, розширенням комунікації для вітчизняних дослідників завдяки відкритості кордонів та вивченням не лише власної музичної культури, але й культури інших держав та народів, у т. ч. і в контексті взаємопроникнення та взаємовпливів. Тож нагромадження позитивних змін проявилося в наукових ідеях, дослідженні нових тем і впровадженні наукових результатів у навчальний процес та практичну діяльність державних установ і громадських організацій.

Тенденції свідчать, що в цьому науковому процесі спостерігається як вивчення нових питань і проблем, так і переосмислення та перегляд вже давно усталених тем.

\section{- Список використаних джерел}

Бондаренко, А.ІІ. (2021). Електронна музика в Україні останньої третини XX початку XXI століття [Дисертація кандидата мистецтвознавства, Київський національний університет культури і мистецтв].

Журба, В.В. (2021). Стиль bebop у джазовій музичній культурі США 1940 - першої половини 1950-х років [Дисертація кандидата мистецтвознавства, Київський національний університет культури і мистецтв].

Журба, Я. О. (2021). Вплив блюзу на неакадемічну музику XX століття [Дисертація кандидата мистецтвознавства, Київський національний університет культури і мистецтв].

Іонов, В. І. (2014). Музична історіографрія та ії сучасні умови. Вісник Національної академії керівних кадрів культури і мистецтв, 3, 159-165.

Київський національний університет культури і мистецтв. (2019). Положення про академічну доброчесність у Київському національному університеті культури i мистеuтв. http://knukim.edu.ua/wp-content/uploads/norm_documents/akadem_ dobro.pdf

Кузьмінський, І. Ю. (2014). Витоки, музична теорія та виконавська практика партесного багатоголосся [Дисертація кандидата мистецтвознавства, Національна музична академія України ім. П. І. Чайковського].

Кузьмінський, І. Ю. (2018). Реформа церковного співу митрополита Петра Могили у Києві. Українська музика, 2, 5-11.

Медведик, Ю. Є. (Уклад.). (2018). Музичне краєзнавство: Робоча програма з навчальної дисципліни. Львівський національний університет імені Івана Франка. https:// kultart.Inu.edu.ua/wp-content/uploads/2019/10/Muzychne-kraieznavstvo.pdf 
Підгорбунський, М.А.(2021). Запровадження багатоголосої музики в українській духовній культурі в контексті реформаційних впливів [Дисертація доктора мистецтвознавства, Київський національний університет культури і мистецтв].

Потапенко, Я. (2015). Рецепція Євромайдану в сучасному українському соціокультурному дискурсі. Наукові записки Інституту політичних $і$ етнонаціональних досліджень ім. І. Кураса НАНУ, 4(78), 4-21.

Рожок, В. (2017). Національна музична академія імені П. І. Чайковського - науковий центр Європи. Українське музикознавство, 43, 4-12.

Скрипнюк, В. М. (1999). Бюрократизм в системі державного управління та правовий механізм його подоламння [Автореферат дисертації кандидата юридичних наук, Національний університет «Одеська юридична академія»].

Шевчук, О. Ю., Кузьмінський І. Ю., \& Зосім, О. Л. (Уклад.). (2021). Українська музична спадщина: нові відкриття: Робоча програма з навчальної дисципліни для аспірантів. Національна музична академі імені П. І. Чайковського. https://knmau. com.ua/wp-content/uploads/025_Ukrainska_muzichna_spadshhina.pdf

Шеремет, В. В. (2021). Народно-інструментальне мистецтво Півдня України (XX початок XXI століття) [Дисертація кандидата мистецтвознавства, Київський національний університет культури і мистецтв].

Malone, K. (2017). "Her Stories Unsung”: embedding feminist activism for social change within musical composition for concert hall programming. Українське музикознавство, 43, 94-111.

\section{- References}

Bondarenko, A. I. (2021). Elektronna muzyka v Ukraini ostannoi tretyny XX - pochatku $X X I$ stolittia [Electronic Music in Ukraine in the Last Third of the $20^{\text {th }}-$ Early $21^{\text {st }}$ Century] [PhD Dissertation, Kyiv National University of Culture and Arts] [in Ukrainian].

Ionov, V. I. (2014). Muzychna istoriohrafiia ta yii suchasni umovy [Music historiography and its current conditions]. National Academy of Managerial Staff of Culture and Arts Herald, 3, 159-165 [in Ukrainian].

Kuzminskyi, I. Yu. (2014). Vytoky, muzychna teoriia ta vykonavska praktyka partesnoho bahatoholossia [Origins, Music Theory and Performance Practice of Party Polyphony] [PhD Dissertation, National Academy of Music of Ukraine Tchaikovsky] [in Ukrainian].

Kuzminskyi, I. Yu. (2018). Reforma tserkovnoho spivu mytropolyta Petra Mohyly u Kyievi [Reform of the church singing of Metropolitan Petro Mohyla in Kyiv]. Ukrainian Music, 2, 5-11 [in Ukrainian].

Kyiv National University of Culture and Arts. (2019). Polozhennia pro akademichnu dobrochesnist u Kyivskomu natsionalnomu universyteti kultury i mystetstv [Regulations on Academic Integrity at the Kyiv National University of Culture and Arts]. http://knukim.edu.ua/wpcontent/uploads/norm_documents/akadem_dobro.pdf [in Ukrainian].

Malone, K. (2017). "Her Stories Unsung": embedding feminist activism for social change within musical composition for concert hall programming. Ukrainian musicology, 43, 94-111 [in English].

Medvedyk, Yu. Ye. (Comp.). (2018). Muzychne kraieznavstvo [Musical Local Lore]: Work program on the discipline. Ivan Franko National University of Lviv. https://kultart.Inu. edu.ua/wp-content/uploads/2019/10/Muzychne-kraieznavstvo.pdf [in Ukrainian]. 
Pidhorbunskyi, M. A. (2021). Zaprovadzhennia bahatoholosoi muzyky v ukrainskii dukhovnii kulturi v konteksti reformatsiinykh vplyviv [Introduction of Polyphonic Music in the Ukrainian Spiritual Culture in the Context of Reformation Influences] [Doctoral Dissertation, Kyiv National University of Culture and Arts] [in Ukrainian].

Potapenko, Ya. (2015). Retseptsiia Yevromaidanu v suchasnomu ukrainskomu sotsiokulturnomu dyskursi [Euromaidan reception in modern Ukrainian socio-cultural discourse]. Scientific Notes Institute of Political and Ethnonational Studies. I. Kuras NASU, 4(78), 4-21 [in Ukrainian].

Rozhok, V. (2017). Natsionalna muzychna akademiia imeni P. I. Chaikovskoho - naukovyi tsentr Yevropy [The Tchaikovsky National Academy of Music is the scientific center of Europe]. Ukrainian musicology, 43, 4-12 [in Ukrainian].

Sheremet, V. V. (2021). Narodno-instrumentalne mystetstvo Pivdnia Ukrainy (XX - pochatok $X X I$ stolittia) [Folk and Instrumental Art of the South of Ukraine (the $20^{\text {th }}-$ the Beginning of the $21^{\text {st }}$ Century)] [PhD Dissertation, Kyiv National University of Culture and Arts] [in Ukrainian].

Shevchuk, O. Yu., Kuzminskyi I. Yu., \& Zosim, O. L. (Comps.). (2021). Ukrainska muzychna spadshchyna: novi vidkryttia [Ukrainian Musical Heritage: New Discoveries] Work program in the discipline for graduate students. National Academy of Music of Ukraine Tchaikovsky. https://knmau.com.ua/wp-content/uploads/025_Ukrainska_muzichna_ spadshhina.pdf [in Ukrainian].

Skrypniuk, V. M. (1999). Biurokratyzm v systemi derzhavnoho upravlinnia ta pravovyi mekhanizm yoho podolannia [Bureaucracy in the System of Public Administration and the Legal Mechanism for Overcoming it] [Abstract of PhD Dissertation, National University "Odesa Law Academy"] [in Ukrainian].

Zhurba, V. V. (2021). Styl bebop v dzhazovii muzychnii kulturi SShA 1940 - pershoi polovyny 1950-kh rokiv [Bebop Style in US Jazz Music Culture of the 1940s - First Half of the 1950s] [PhD Dissertation, Kyiv National University of Culture and Arts] [in Ukrainian].

Zhurba, Ya. O. (2021). Vplyv bliuzu na neakademichnu muzyku XX stolittia [The Influence of Blues on Non-academic Music of the Twentieth Century] [PhD Dissertation, Kyiv National University of Culture and Arts] [in Ukrainian]. 


\section{- HISTORICAL DOCUMANTATION} OF DOMESTIC SCIENTIFIC RESEARCH OF MUSIC CULTURE IN THE PRESENT CONDITIONS

\section{- Nataliia Mohylevska}

- People's Artist of Ukraine, ORCID: 0000-0002-7102-2114, e-mail: mogylevska-nataliia@ukr.net, Kyiv National University of Culture and Arts, Kyiv, Ukraine

\section{- Abstract}

The article considers the conditions for studying music culture, which affect the development of scientific knowledge. The purpose of the article is to find out the peculiarities of the development of scientific research of music culture in the context of today's Ukraine within national and global processes. The research methodology consists of general scientific and specialised methods. The general scientific methods include logical and dialectical approaches, and specialised methods are systemic and historical-comparative. Conclusions. It is determined that at the initial stage of research of music culture, many works had the transitional format. However, the new archival materials discovery and access to world achievements changed the situation in the direction of the interdisciplinary approach, which forced reconsidering established stereotypes. It is emphasised that in reforming both the state as a whole and its individual institutions, the fight against plagiarism and the requirement to expand publications in scientometric databases had a significant impact on the development of music culture research. However, higher education institutions and academic research institutions have not been able to get rid of bureaucratic control, and in the reform process, no formula has been proposed by which the scientific community could determine the effectiveness of the publication of scientific results. The national and globalisation influence on the efficiency of scientists' activity is emphasised. It is determined that today we can already talk about a number of research centres where music culture issues are studied, notably - the Ukrainian National Tchaikovsky Academy of Music, Kyiv National University of Culture and Arts, and other institutions. Therefore, the accumulation of favourable changes was manifested in scientific ideas, research of new topics and implementation of scientific results in the educational process or practical activities of government agencies and NGOs.

Keywords: music culture; science; journal; post-Soviet period; globalisation; national interests; Kyiv National University of Culture and Arts; academic integrity 


\section{- ИСТОРИОГРАФИЯ ОТЕЧЕСТВЕННЫХ НАУЧНЫХ ИССЛЕДОВАНИЙ МУЗЫКАЛЬНОЙ КУЛЬТУРЫ В СОВРЕМЕННЫХ УСЛОВИЯХ}

\section{- Могилевская Наталья Алексеевна}

- Народная артистка Украины,

ORCID: 0000-0002-7102-2114, e-mail: mogylevska-nataliia@ukr.net, Киевский национальный университет культуры и искусств, Киев, Украина

\section{- Аннотация}

В статье рассматриваются условия проведения исследования музыкальной культуры, влияющих на развитие научных знаний. Цель статьи - выяснить особенности развития научных исследований музыкальной культуры в условиях современной Украины в контексте национальных и глобальных процессов. Методология исследования состоит в общенаучных и специальных методах. К первым относятся логический и диалектический методы, а ко вторым - системный и историко-сравнительный. Выводы. Определено, что на начальном этапе исследований музыкальной культуры многим наработкам был свойственен переходный формат, однако открытие новых архивных материалов и доступ к мировым достижениям изменили ситуацию в направлении развития междисциплинарного подхода, который заставляет пересмотреть установленные стереотипы. Отмечается, что в процессе реформирования как государства в целом, так и отдельных его институтов значительное влияние на развитие исследований музыкальной культуры сыграла борьба с плагиатом и требование расширения публикаций в наукометрических базах. Однако высшие учебные заведения и академические научные учреждения не смогли избавиться от бюрократического контроля, а в процессе реформирования не было предложено формулы, по которой научное сообщество могло бы определять эфрфективность обнародования научных результатов. Подчеркивается национальное и глобализационное влияние на эффективность деятельности ученых. Определено, что сегодня уже можно говорить о существовании ряда научных центров, где изучаются проблемы музыкальной культуры, в частности - это Национальная музыкальная академия Украины имени П. И. Чайковского, Киевский национальный университет культуры и искусств и другие учреждения. Накопление положительных изменений проявилось в научных идеях, исследовании новых тем и внедрении научных результатов в учебный процесс или практическую деятельность государственных учреждений и общественных организаций.

Ключевые слова: музыкальная культура; наука; журнал; постсоветский период; глобализация; национальные интересы; Киевский национальный университет культуры и искусств; академическая доброчестность 